\title{
The Sensationalization of the "Homophobic Muslim": Tracing the Roots of Islamophobia and Homophobia
} N. Safdari*, Ethnic Studies

\begin{abstract}
Within the white supremacist imaginary has emerged a highly sensationalized figure: the "homophobic Muslim." Islam's proximity to Blackness fosters the Islamophobic ascription of criminality and bigotry to Muslims. Homophobia and heterosexism, however, in addition to the notions of gender and sexuality themselves, are white supremacist constructs, dating back to the Middle Passage. Thus, the "homophobic Muslim" narrative operates as a branch of white supremacy, positioning the racialized migrant subject as both illegitimate and threatening, as well as camouflaging the innate anti-Blackness of homophobia altogether. Through examination of the works of numerous preeminent Black feminists and other LGBT academics of color, this paper delves into the anti-Black origins of Islamophobia and the Islamophobic nature of the dissemination of the "homophobic Muslim" in popular discourse, as well as the coloniality of gender, sexuality, and homophobia. Labeling Muslims as the source of homophobia and bigotry more generally also functions to justify structural violence against the "homophobic Muslim" at the same time that it claims that such a figure is a threat to the neoliberal democracy. Findings include the examination of Iran's sociopolitics and the relationships between contemporary LGBT folks and their Muslim families. Further research is necessary to establish a clear relationship both between the "homophobic Muslim" fiction and real, material violence committed against Muslim individuals, and between the imposition of Western heteropatriarchal systems around the world and the persistence of bigoted attitudes towards homosexuality in imperialized regions, while white spaces increasingly claim to be moving in "progressive," liberal directions.
\end{abstract}

\section{INTRODUCTION:}

Widespread in the West is the sensationalization of the "homophobic Muslim," as well as a moral panic pertaining to such a figure. As Western nation-states increasingly proclaim that they are moving in more "progressive" directions, white communities often cast misogyny and homophobia under an Orientalist light (Snorton and Haritaworn 71). Situating Eastern populations as uncivilized and inferior to those in the West leads to the attribution of bigotry and violence against gender/sexual minorities to Islam. Beneath this misconception, of course, lies an

* N. Safdari is finishing up the fourth and final year of their Bachelor of Science at the University of Oregon. Their research focuses primarily on Ethnic Studies, specifically Black feminist theory, LGBT of color theorizing and critique, and Islamophobia in the Western world. When they are not reading or writing, they are watching an independent film or listening to Frank Ocean, Janelle Monáe, or Rihanna. Please direct correspondence to nsafdari@uoregon.edu. 
Islamophobic undercurrent, which itself acts as part of a greater project of white supremacy (Smith 2). Furthermore, anti-Blackness serves as the fulcrum of white supremacy and is fundamental to the understanding of Islamophobia, which in turn functions to persecute and delegitimize migrants, whose Islamic faith is thought to be antithetical to whiteness (Beydoun). Painting Islam as the face of homophobia falsely incriminates the racialized Muslim migrant and disregards the colonial roots of homophobia and heterosexism, as well as the prevalence of Islamophobia in the West. Gender and heterosexism being colonialist and anti-Black notions themselves, the "homophobic Muslim" acts as one of the many facets of the white supremacist imaginary, positioning the racialized migrant subject as both illegitimate and threatening and evading the inherent whiteness and anti-Blackness of homophobia altogether. Through examination of the anti-Black roots of Islamophobia, the ascription of criminality to both Black and Muslim communities, quintessential examples of the propagation of the "homophobic Muslim" in popular discourse, the coloniality of homophobia, and a contemporary case study of homophobia within an Islamic nation-state, it becomes clear that both Islamophobia and homophobia are products of white supremacy and that the "homophobic Muslim" is nothing more than a scapegoat.

\section{ISLAMOPHOBIA \& ANTI-BLACKNESS INTERTWINED:}

First, it is vital to establish the anti-Black, white supremacist origin and nature of Islamophobia. Although there are particular axes along which anti-Blackness uniquely operates in the oppression of Black populations and individuals, anti-Blackness affects and forms the basis for all forms of racism. In a multi-faceted analysis of Islamophobia by the reputable news source Al Jazeera, Khaled Beydoun explores the deeply anti-Black nature of Islamophobia, which is at its root a racial project and the spawn of white supremacy. Beydoun writes that while giving a lecture on his book, American Islamophobia: Understanding the Roots and Rise of Fear, someone approached him and asked why a Black woman was on the cover (Beydoun). Their encounter exemplifies the dissonance between the public image of the Muslim figure that is propagated in the U.S. and the actual constituency and demographic composition of Muslims in the U.S. Not only do many contemporary Black Americans identify as Muslim, but 93 percent of the inhabitants of the North Africa-Middle East region are Muslim, along with 30 percent in subSaharan Africa (Desilver and Masci). Furthermore, "within the population of enslaved Africans who were brought to North America, historians estimate between 20-30\% of them were Muslim" (Nessa). It is clear that a significant proportion of Black communities, both inside and outside of the U.S., practice Islam and are associated with it, contributing to dual, interdependent oppressions in the form of anti-Blackness and Islamophobia against Black Muslims. Beydoun goes on to say, "Islamophobia in the United States is, in great part, a racial project, spawned by a master discourse that drove European supremacy and today powered by popular views and state policy seeking to safeguard its domestic progeny, white supremacy" (Beydoun). Islamophobia, then, is inextricable from white supremacy and its objective of establishing anti-Blackness. White supremacy has necessitated anti-Blackness from its very conception, as white and Black were and are positioned as diametrically opposed to one another. After all, in the white supremacist project of Islamophobia, the proximity of Islam to Blackness and of its origin to East, rather than West, 
forms the basis for the discrimination against its followers: "From 1790 until 1952, American naturalisation law mandated whiteness as a prerequisite for naturalised citizenship, and until the Ex Parte Mohriez decision 1944, Muslims were viewed as a distinct racial group that was not only non-white, but members of a faith held out to be the civilisational antithesis of whiteness" (Beydoun). Through the propagation of Orientalism, Islam has been situated as the metaphorical face of the East, running counter to the West and posing a threat to it. In other words, Orientalist logic-with its innate anti-Blackness-posits that Islam is the antipode of whiteness, which forms the basis for Islamophobia.

In the examination of Islamophobia in the U.S., the aforementioned question of citizenship and naturalization is an interesting one. Due to the anti-Black, white supremacist nature and function of the U.S. state from the very beginning of its foundation, the right of citizenship was instituted to legitimize and substantiate the superior social position of the white American, while necessarily excluding the Black individual. It was not until 1868 that the right of citizenship of former slaves and their Black progeny was inscribed into U.S. legislation through the Fourteenth Amendment (Art./Amend. XIV, Sec. 1). Until then, citizenship (and, more generally, legality) belonged to whites only. Importantly, Black folks living in America do not enjoy the same right of citizenship as their white counterparts even now. The Constitution may claim to protect them; reality is entirely different altogether. In his academic journal article "Take Me Home': Location, Identity, Transnational Exchange," cultural critic and Black American Phillip Brian Harper reflects on the actual lived experiences of the Black U.S. "citizen." He recounts having been awakened to their status as a second-class citizen during a business trip to Canada. He remarks,

[A]gainst all reason-and contrary to what I had been taught to expect in any number of other contexts-I had come to see myself as having an unproblematic claim at least to the title of U.S. citizenship, if not to all its perks and benefits, at most any point along the border with Canada-a typical condition of profound U.S.-nationalist myopia from which I was not adequately jolted until my experience in Toronto in December 1997. And yet, once that jolt took place, I immediately recurred to my default mode for negotiating the verge of subjective illegitimacy on which all nonnormative citizens are aware that we perennially teeter. (Harper 466)

Nonnormative citizens, particularly those who are Black, cannot lay claim to the same rights and protections as other American citizens. It is this same fundamental anti-Blackness in the exclusion of Harper from true U.S. citizenship access that precludes the Muslim person-similarly to and yet (at least in the case of non-Black Muslims) also differently from the Black person-from attaining full, legitimatized citizenship rights. The Ex Parte Mohriez decision 1944, as Beydoun cites, grants legal access to citizenship to Muslims in the U.S., but the anti-Blackness inherent in U.S. citizenship access and the proximity of the Muslim identity to Blackness (and, dialectically, its metaphysical distance from whiteness) together ensure that, regardless of their legal documentation status as citizens, Harper and the Muslim individual alike are not treated as such.

Yet another component of the anti-Blackness integral to Islamophobia is the criminalization of Muslims, involving both the ascription and subsequent presumption of criminality in People of 
Color. Having established that anti-Blackness is at the core of Islamophobia, it is imperative to unearth the anti-Blackness that underscores the characterization of Muslims as violent and threatening. Political activist and Black feminist Angela Davis argues in the chapter "Slavery, Civil Rights, and Abolitionist Perspectives Toward Prison" of her book Are Prisons Obsolete?, that the prison industrial complex, or PIC, not only allows, but actually aims for, the continued enslavement of Black folks in the U.S. Thus, U.S. socio-political discourse axiomatically requires, as Frederick Douglass so fittingly put it, the "imputation of crime to color" (Davis 30). Davis expands upon Douglass' assertion: "During the post-slavery era... black people were imprisoned under the laws assembled in the various Black Codes of the southern states, which, because they were rearticulations of the Slave Codes, tended to racialized penality and link it closely with previous regimes of slavery" (Davis 31). Therefore, compounded upon the 13th Amendment, which contends that "[n]either slavery nor involuntary servitude, except as punishment for a crime whereof the party shall have been duly convicted, shall exist within the United States" (Art./Amend. XIII), it is evident that the intention of the PIC is to continue the legacy and practice of the enslavement of Black bodies.

Davis goes on to say, "In the aftermath of the September 11 attacks, vast numbers of people of Middle Eastern and South Asian heritage were arrested and detained by the police agency known as Immigration and Naturalization Services (INS)" (Davis 31). Her observation is echoed and supplemented by Beydoun, who declares,

The tropes that drove the formative legal position that Muslims were non-white, and oriented Islam as antithetical to whiteness, were 'redeployed' after the 9/11 attacks. That moment that spurred the bleak aftermath that gave rise to Islamophobia as we know it today, spearheaded by the creation of the Department of Homeland Security (DHS) and the initiation of the war on terror. Therefore, the ideas and images, distorted narratives and misrepresentations thrust to the surface after 9/11 that steer Islamophobia today were sowed and legally sealed by Orientalism, which must be understood as the mother of modern Islamophobia. (Beydoun)

The criminalization of Muslims following the September 11 attacks is, ergo, built upon Islam's oppositional position in relation to whiteness and the foundational incrimination of Black communities in violence and delinquency. The so-called "war on terror" also invokes Orientalism, which denominates Muslims and "Eastern" peoples a threat to the U.S. empire, and moreover, its Orientalist derivation reveals that, as Sora Han put it, "the United States is not at war; the United States is war. For the system of white supremacy to stay in place, the United States must always be at war" (Smith 2-3). Waging wars against the Black community and, more generally, all communities of color-through criminalization and the construction of the PIC, in this caseupholds white supremacy and ensures that it continues to flourish.

\section{THE "HOMOPHOBIC MUSLIM" IN POPULAR DISCOURSE:}

The attribution and imputation of crime to Muslims in particular is perhaps most evident in the highly sensationalized "homophobic Muslim" narrative. Specifically in white queer 
theorization and critique, the Muslim (or, commonly in popular discourse, Middle Eastern, North African, or South Asian) figure often personifies the diametrical "other" of the modern, sexually liberated (white) queer individual. Feminist scholar Gayatri Gopinath delves into the relationship between the Muslim character and its supposedly oppositional white, queer character in her work, "Bollywood Spectacles: Queer Diasporic Critique in the Aftermath of 9/11." As an example, she examines the photography of South Asian artist Parminder Sekhon, and in particular one piece entitled "Southall Market." The photograph features Sekhon herself, a young, queer woman (in the nude), standing anterior to her older, Muslim mother. Read through a "liberal feminist" lens, Gopinath articulates that the image symbolizes the binary divisions between Sekhon and her mother-of tradition and modernity, queerness and heterosexuality, visibility and invisibilitywhich align with hegemonic representations of South Asian immigrants whom Western society deems unassimilable (Gopinath 166). Such a colonial reading exists not bearing in mind but in spite of the fact that "Sekhon's queerness is formed in and through her relation to 'home' space, even as it radically disrupts and territorializes this space" (Gopinath 167). Western nationalist discourse, in and through its white supremacist framework, paints the Muslim as a sort of archaic figure, whose beliefs and faith are incongruous with the liberal "progress" of whiter, more WASPcentered socio-political spheres, and are supposedly fundamentally antiquated and homophobic.

A similar and perhaps even more harrowing instance of such an Islamophobic rendering of the Muslim individual occurs in queer circles in Germany, as depicted in the work "Trans Necropolitics: A Transnational Reflection on Violence, Death, and the Trans of Color Afterlife." The authors meditate on "racist homonationalist mobilizing" and the moral panic over the "violent," "homophobic Muslim" (Snorton and Haritaworn 67) in one gentrifying, migrant Turkish area of Germany. There, the authors write, the image of the homophobic migrant is spectacularized through the broadcasting of hate crimes against gender non-conforming subjects. The multiculturalism crisis in Europe and "Muslim test" of German citizenship give rise to the perfect conditions under which to center homonormative and homonationalist organizing working to eradicate the "homophobic Muslim" figure. Although the exploitation of poor, racialized sex workers has been unremarkable to German queer and trans activists for quite some time, one particular Drag Festival drew the attentions of such activists to the violence against trans individuals occurring in a migrant-majority neighborhood. White activists took to the streets with their megaphones and capitalized upon the sensationalization of the violence against trans sex workers by attributing all the blame to migrant youth (of color) gangs, despite the fact that most of the victims were and always have been migrant trans sex workers. Of course, such a distinction was not made (Snorton and Haritaworn 72). As with "Southall Market," dominant white discourse and critique lends itself to the scapegoating of the "homophobic Muslim," who is cast as anachronistic and threatening, under the guise of a homogenous, neoliberal, white movement towards "progress."

\section{THE COLONIALITY OF GENDER, SEXUALITY, \& HOMOPHOBIA:}

Constructing the "homophobic Muslim," however, disregards the colonialist origin of homophobia and functions only to further disseminate the seeds of white supremacy and 
Islamophobia. Renowned Black feminist Cheryl Clarke, in her chapter "The Failure to Transform" of the book Home Girls: A Black Feminist Anthology, definitively derives the fundamental origin of homophobia and heterosexism as emerging from white, Western culture and practice. She calls it a "Puritan value" that "sex is for procreation, occurs only between men and women, and is only valid within the confines of a heterosexual marriage" (Clarke 199), as well as a "Western institution" and "Christian fundamentalist notion" that sex is viewed as "sin" (Clarke 201). Here, not only are heterosexism and homophobia decidedly Western in nature, but are also more explicitly non-Muslim, as they are Christian and more specifically Puritan. Furthermore, although Clarke herself argues that "we cannot rationalize the disease of homophobia among black people as the white man's fault" (Clarke 197), she does not contend that the cause of homophobia within Black communities (or, in this case, Muslim communities) cannot be traced back to the white man, only the "disease" as it presently stands. Similarly, distinguished Black feminist Audre Lorde also comments on homophobia in the Black community in the piece "Age, Race, Class and Sex: Women Redefining Difference” in her book Sister Outsider: Essays and Speeches. Notably, she writes, "Black women who once insisted that lesbianism was a white woman's problem now insist that Black lesbians are a threat to Black nationhood, are consorting with the enemy, are basically un-Black" (Lorde 121). Her assertion reveals an interesting additional layer of the homophobia existing within the Black community (which are not equal to but, for the purpose of analyzing the case of the "homophobic Muslim," being extrapolated to communities of color more generally). When she says "basically un-Black," she evokes a certain sense of perceived betrayal to the Black community on the part of gender/sexual minorities. Bearing in mind the intersectionality of oppression, the Black community may subscribe to an imposed practice of compulsory heterosexuality so as to attempt to shield itself from multiple, compounding axes of subjugation, rendering gender/sexual minorities as "traitors to the race" whose resistance to hegemonic white cultural norms necessitates and justifies the persistence of homophobia as a means by which to stifle and silence them. The pervasion of homophobia in the Black community and other communities of color does not, however, contradict its colonial, Puritan origins.

Moreover, Black feminist scholar Hortense Spillers exhumes the earliest vestige of the antiBlack constructs of normative gender and sexuality (and, by proxy, the pathology of homophobia) in her paramount work "Mama's Baby, Papa's Maybe: An American Grammar Book." Spillers therein theorizes that the Middle Passage symbolized a sort of "rupture" in human history, leading to the "theft of the body" of the captive African, whose sexuality became a biological "Other" and who began to embody physical powerlessness at the hands of the white male captor (Spillers 67). The Black body being the most phenotypically distinct from the European captor, in terms of the "riffs of melanin in the skin" (Spillers 70), the captor embarked upon a "dehumanizing, ungendering, defacing project of African persons" (Spillers 72). Through this project, however, the white male paradoxically both ungendered the African body with reproductive capacity and simultaneously, by means of the partus sequitur ventrem, labeled such a body a "mother" in order to ascertain that the "slave mother is 'forever entailed on all her remotest posterity" (Spillers 79). Spillers goes on to say, "such naming is false because the female could not, in fact, claim her child, and false, once again, because 'motherhood' is not perceived in the prevailing social climate as a legitimate procedure of cultural inheritance" (Spillers 80). The African female, therefore, 
epitomized the conduit between humanity and property, with her ungendered flesh receiving the title of "mother" only to relegate the slave condition to her offspring. The dehumanization of forcibly enslaved Africans, from the Middle Passage and onward, also created the circumstances that fostered the birth of white subjectivity, in terms of gender and sexuality. Gender, then, served only to assign fungibility to the African female and perpetuate the condition and practice of slavery, and it is therefore necessarily anti-Black. The coloniality and anti-Blackness of gender and sexuality also render any gender- or sexuality-based oppressions the product of white supremacy, including homophobia. Painting Islam as the face of homophobia and heterosexism, ergo, is not only entirely foundationless but additionally, due to the white supremacist and colonialist origins of both Islamophobia and homophobia, absurdly counterfactual.

\section{RELEVANT FINDINGS:}

A quintessential contemporary exemplification of the Islamophobic nature of the "homophobic Muslim" and the white supremacist nature of homophobia is the case of the country of Iran and my own Muslim, Iranian grandmother. Currently, Iran is extremely intolerant of homosexuality and any gender/sexual deviance. Interestingly, however, although the Quran "address[es], and generally condemn[s], sexual relations between members of the same sex," in premodern times, homoerotic poetry was very common. Historians believe that "[i]n late medieval Iran... Sufi and literary manifestations of homoeroticism became increasingly intertwined, resulting in the peculiarly Persian phenomenon of love lyrics whose referents-a boy? God? a woman?-regularly defy any attempt at a literalizing or reductionist analysis" (Rowson). Not only does premodern and medieval Iranian poetry include references to homoerotic sexual practices, but notably, it contains "love lyrics," which verify the existence of a homoromantic erotic life for some individuals in Iran during these time periods. Present-day Iran, in contrast, is marked by post-imperialism. The 1979 Iranian Revolution itself occurred in large part due to the continued omnipresence of white forces-military and otherwise-in the Middle East. Iranian journalist Akbar Ganji documents, "in broad terms, Iranian revolutionaries wanted independence from foreign control and were critical of Western intervention in support of despotism. The Shah of Iran was considered to be the regional gendarme of American imperialism in the Middle East" (Ganji). European and American imperialism have touched every corner of the planet. In the particular case of Iran, white domination took place formally until 1979 (and informally continues to this day, in many ways), and it is impossible to know what attitudes towards homosexuality would be if not for the prevalence of white supremacy and its stakeholders. Thus, when I examine the case of my own homophobic grandmother, it is both reductive and inaccurate to dismiss her with a wave of the "homophobic Muslim" wand, and it is inconceivable to understand the reasons for which Western neoliberals have contrived such a category within which to contain her without deeply reckoning with white supremacy, anti-Blackness, and their manifestation in the form of Islamophobia. 


\section{CONCLUSION:}

The scapegoating of the "homophobic Muslim" operates as a branch of the anti-Black construct of Islamophobia to further the greater Western project of white supremacy. Islamophobia contributes to Western beliefs about white supremacy and takes the form of the sensationalization of the "homophobic Muslim" in self-professedly "progressive" white spaces. White supremacy itself, of course, in turn functions to structurally and violently decimate the "homophobic Muslim," ironically, at the same time that it claims that such a figure is a threat to the neoliberal democracy. In actuality, homophobia emerges in conjunction with the colonial, anti-Black notions of gender and sexuality, which are themselves fictions invented by the white male in the process of creating a slave-based economy, to use against the African female in order to make heritable the condition of enslavement. Homophobia, like Islamophobia, is the white man's creation, rather than-as Western alarmist narratives would prefer to suggest-a pathology stemming from the followers of the Islamic faith. The "homophobic Muslim," therefore, as part of the white supremacist imaginary, is a fabricated classification and-in order to dismantle the insidious Western notions of anti-Blackness, Islamophobia, and homophobia-must be deconstructed.

\section{ACKNOWLEDGMENTS}

I would like to acknowledge my professors for facilitating my knowledge production and inquiry, particularly Dr. Shoniqua Roach; the Black feminists and other queer scholars of color whose labor and works I utilized and gained inspiration from; my fellow queer folks who struggle to survive every day and yet manage to keep going; my fellow People of Color, whose legitimacy and humanity are called into question on a regular basis and who refuse ever to quit fighting for our liberation; my partner, whose love sustains me in the face of all injustice and without whom I might not see the beauty in the world; and my closest family, who, despite innumerable cultural barriers, loves me as I am.

\section{REFERENCES}

Beydoun, Khaled A. "Rethinking Islamophobia.” Al Jazeera, 12 Mar. 2018, www.aljazeera.com/indepth/opinion/rethinking-islamophobia-180312085500278.html. Accessed 10 Feb. 2019.

Clarke, Cheryl. "The Failure to Transform.” Home Girls: A Black Feminist Anthology, edited by Barbara Smith, Kitchen Table, 1983, pp. 197-208.

Davis, Angela. "Slavery, Civil Rights, and Abolitionist Perspectives Toward Prison.” Are Prisons Obsolete? Seven Stories Press, 2003, pp. 22-39.

Desilver, Drew, \& David Masci. "World Muslim population more widespread than you might think.” Pew Research Center, 31 Jan. 2017, www.pewresearch.org/facttank/2017/o1/31/worlds-muslim-population-more-widespread-than-you-might-think. Accessed 16 Mar. 2019. 
Harper, Phillip B. “Take Me Home’: Location, Identity, Transnational Exchange.” Callaloo, vol. 23, no. 1, 2000, pp. 461-478.

Ganji, Akbar. "Post-Imperialism in Iran.” Frontline, 16 Feb. 2010, www.pbs.org/wgbh/pages/frontline/tehranbureau/2010/o2/akbar-ganji-on-postimperialism-in-iran.html. Accessed 17 Mar. 2019.

Gopinath, Gayatri. "Bollywood Spectacles: Queer Diasporic Critique in the Aftermath of 9/11.” Social Text, vol. 23, no. 3-4, 2005, pp. 157-169.

Lorde, Audre. “Age, Race, Class and Sex: Women Redefining Difference.” Sister Outsider: Essays and Speeches, Crossing Press, 1984, pp. 114-123.

Nessa. “The (Anti) Black A** Roots of America's Islamophobia.” The Body Is Not an Apology, 19 May 2018, thebodyisnotanapology.com/magazine/the-anti-black-ass-roots-of-americasislamophobia. Accessed 16 Mar. 2019.

Rowson, E.K. "Homosexuality ii. In Islamic Law." Encyclopædia Iranica, vol. 7, no. 4, 23 Mar. 2012, www.iranicaonline.org/articles/homosexuality-ii. Accessed 18 Mar. 2019.

Smith, Andrea. "Heteropatriarchy and the Three Pillars of White Supremacy: Rethinking Women of Color Organizing.” Color of Violence: The Incite! Anthology, edited by Incite! Women of Color Against Violence, South End Press, 2006, pp. 1-6.

Snorton, C. Riley, \& Jin Haritaworn. "Trans Necropolitics: A Transnational Reflection on Violence, Death, and the Trans of Color Afterlife." The Transgender Studies Reader, edited by Aren Aizura \& Susan Stryker, vol. 2, Routledge, 2013, pp. 66-76.

Spillers, Hortense J. “Mama’s Baby, Papa’s Maybe: An American Grammar Book.” Diacritics, vol. 17 , no. 2,1987, pp. 64-81.

U.S. Constitution. Art./Amend. XIII.

U.S. Constitution. Art./Amend. XIV, Sec. 1. 